\title{
Targets and abuse: the price public health campaigners pay
}

\author{
Public health advocates are subjected to increasing \\ levels of abuse, some of which may be orchestrated
}

W ith 40 books and some 800 publications, Professor Martin McKee is the United Kingdom's foremost public health academic. Professor Stanton Glantz of the University of California, custodian of millions of tobacco industry documents, has been a leading researcher and campaigner for decades. Professor Simon Chapman of the University of Sydney and I have been prominent tobacco control campaigners nationally and overseas since the early 1970s. Yet a prominent blogger who disagrees with us about e-cigarettes tweeted that we are the "world's top cigarette salesmen".

\section{"When we succeed, lives are saved; if they and their allies succeed ... there is more premature death, disease, injury and community harm"}

That is mild compared with some attacks on public health advocates that go far beyond robust debate. Personal abuse and four-letter invective in blogs, tweets and emails are commonplace. Among the gentler comments, tobacco control leaders are liars, frauds, imbeciles, stupid, hate-filled, unethical, dishonest, hysterical, contemptible, insanely wicked, evil, sick, lunatics and paid tools of the pharmaceutical industry. McKee is "one of the most primordial bottom-feeders in all social media"; Chapman is a "scrotum-faced head-banger"; Glantz is compared with Hitler; I am a "c... coat". ${ }^{2}$ Within a day of the Charlie Hebdo murders in Paris, bloggers and tweeters were drawing parallels between tobacco campaigners and Islamic State. ${ }^{3}$

Being on the receiving end is unpleasant and intimidating. After publishing a straightforward article about e-cigarettes, one of Australia's brightest young health researchers was last year moved to write, "I think my ecig commentary days are donehaven't got the stomach for the gross Twitter trolls that descended or the internet vermin that took over the comments" (personal communication).

The e-cigarette lobby specialises in this kind of abuse, but it goes much further. Dirty politics, a recently published book by New Zealand journalist Nicky Hager, includes disturbing allegations about the roles of tobacco, alcohol and food companies, such as payments to a public relations consultant for activities including online attacks on their critics. ${ }^{4}$
Mike Daube AO, BA(Hons), DSci(Hons) Curtin University, Perth, WA. m.daube@curtin.edu.au

doi: 10.5694/mjal5.00059
There is a long history of attempts by tobacco companies and their allies to discredit people they see as threats - in Australia, these even include searches through rubbish bins of health groups. ${ }^{5}$ Are they behind some of the social media abuse? We may never know the full story, but history is a good guide.

My first encounter with their approach was in London 40 years ago. A Financial Times journalist told me that the tobacco industry had alerted him to a note in our annual accounts, which they thought showed I was spending large sums on hospitality. Alas, it was merely luncheon vouchers, which were then part of secretarial staff remuneration. The journalist was not interested in my suggestion that tobacco company attempts to discredit ASH (Action on Smoking and Health) might be newsworthy - and later went to work for the industry. Since then, I have been offered money to work in other areas, spied on, followed, threatened, sued (unsuccessfully), abused and much more.

The attempts to discredit continue, whether from tobacco companies themselves, "think-tanks", Twitter or shadowy bloggers. My integrity was recently impugned by a micro-organisation with a loftysounding name, whose website showed precisely one blogger, and which is associated with groups with a history of tobacco funding. ${ }^{6}$ They made imputations that were nasty and untrue - but attracted media coverage, which was presumably the intention.

All that is, of course, over and above the abuse we get from those with commercial interests in tobacco and alcohol and groups directly associated with them, such as the Australian Hotels Association, who specialise in meaningless phrases such as "wowser", "nanny state", "zealot" and "prohibitionist", and attack health groups including the Australian Medical Association, ${ }^{7}$ or prominent individuals such as police commissioners, ${ }^{8,9}$ with wild assertions and distasteful comments about personal motivation.

There is nothing new about attacks on public health advocates. In the mid 19th century, when Edwin Chadwick was campaigning for what we now 
recognise as the start of the sanitary revolution, the London Times editorialised, "We prefer to take our chances of cholera and the rest than be bullied into health". ${ }^{10}$ The difference, in Peter Draper's phrase, is that, thanks to the promotional and public relations activities of powerful global industries, we have moved from pollution of the drinking water to pollution of the thinking water. ${ }^{11}$

So what conclusions do I draw from this?

My perception from working across a range of problems including tobacco, alcohol, obesity and gambling is that in recent years public health advocates have been subjected to increasing levels of personal abuse, from industry organisations and their allies through to social media. I find it hard to believe that at least some of this is not planned and orchestrated.

A recent McKinsey report rated tobacco as first among the global social burdens generated by humans, ahead of "armed violence, war and terrorism". ${ }^{12}$ Each year, tobacco and alcohol cause more than nine million deaths globally. ${ }^{13,14}$ The two industries are immensely powerful, closely linked, use many of the same tactics, and are intent on preventing any measures that might conflict with their interests. When we succeed, lives are saved; if they and their allies succeed, because of their economic power and their access to politicians, there is more premature death, disease, injury and community harm.

Simon Chapman advises public health advocates that they need to "grow a rhinoceros hide". ${ }^{15} \mathrm{He}$ is right, but the battles are wearying and the abuse can be distressing. We are bound by evidence, rational argument and decency - they are not. As the personalised attacks increase, and social media becomes ever more accessible, health organisations and leaders will need to provide strong support for the next generations of campaigners.

McKee, Glantz and Chapman have made enormous contributions to global and national public health, in tobacco control and well beyond. When the American Cancer Society awarded me its Luther Terry Distinguished Career Award in 2012, the citation noted that "he has contributed to saving millions of lives". ${ }^{16}$ I will take that over abuse from tobacco and alcohol companies, industry associations and malicious bloggers any day.

Competing interests: No relevant disclosures.

Provenance: Not commissioned; not externally peer reviewed.

References are available online at www.mja.com.au. 
1 Bates C. [Twitter post]. 2014; Dec 12. https://twitter.com/ Clive_Bates/status/543370683410305024 (accessed Jan 2015).

2 Snowdon C. [Twitter profile]. https://twitter.com/cjsnowdon (accessed Jan 2015).

3 Davis F. Signature policies. Velvet Glove, Iron Fist 2015; Jan 8. http://velvetgloveironfist.blogspot.co.uk/2015/01/signaturepolicies.html (accessed Jan 2015).

4 Hager N. Dirty politics: how attack politics is poisoning New Zealand's political environment. Nelson, New Zealand: Craig Potton Publishing, 2014.

5 Simpson D. Australia: epidemiology classes, shredding, and calls to "the garbageman": a day in the life of tobacco folk. Tob Control 2005; 14: 75-76.

6 Australian Taxpayers' Alliance [website]. http://www. taxpayers.org.au (accessed Jan 2015).

7 Liquor Control Act Review [television]. ABC News 2014; Jan 15. https://www.youtube.com/watch?v=us8QLoHrOtl (accessed Jan 2015).

8 Emerson D. Split over early pub hours. The West Australian 2013; Sep 27. https://au.news.yahoo.com/ thewest/a/19130695/split-over-early-pub-hours (accessed Jan 2015).

9 End alcohol advertising in live sport: O'Callaghan. ABC News 2013; Jun 19. http://www.abc.net.au/news/2013-06-19/ premier-denies-lack-of-resources-making-policingdifficult/4765070?\&section=news (accessed Jan 2015).
10 Chapman S. One hundred and fifty ways the nanny state is good for us. The Conversation 2013; Jul 2. http:// theconversation.com/one-hundred-and-fifty-ways-thenanny-state-is-good-for-us-15587 (accessed Jan 2015).

1 Daube M. Advocating for children. J Paediatr Child Health 2013; 49: 9-12.

12 Dobbs R, Sawers C, Thompson F, et al. Overcoming obesity: an initial economic analysis. Discussion paper. McKinsey Global Institute, 2014. http://www.mckinsey.com/ /media/ McKinsey/dotcom/Insights/Economic\%20Studies/How\%20 the\%20world\%20could\%20better\%20fight\%20obesity/ MGI_Overcoming_obesity_Full_report.ashx (accessed Mar 2015).

13 World Health Organization. Global status report on alcohol and health 2014. Luxembourg: WHO, 2014. http://apps.who. int/iris/bitstream/10665/112736/1/9789240692763_eng.pdf (accessed Mar 2015).

14 World Health Organization. Global status report on NCDs 2010. WHO, 2011. http://www.who.int/chp/ncd_global_ status_report/en (accessed Mar 2015).

15 PHAA Annual Conference Report. In Touch in WA [newsletter]. Public Health Association of Australia (WA Branch), November 2014: 2. http://www.phaa.net.au/ documents/141107PHAA\%20NewsletterNov\%202014\%20 FINAL\%20(2).pdf (accessed Mar 2015).

16 American Cancer Society. 2012 Luther L Terry Award Winners. http://www.cancer.org/aboutus/honoringpeoplewhoarem akingadifference/lutherterryawards/lutherterryrecipients/ Ita_winners_2012 (accessed Jan 2015). 